\title{
Adolescent Time Attitude Scale: Adaptation into Turkish
}

\author{
Eyüp Çelik ${ }^{1, *}$, Ümit Sahranç ${ }^{1}$, Mehmet Kaya ${ }^{1}$, Mehmet Emin Turan ${ }^{2}$ \\ ${ }^{1}$ Sakarya University, Faculty of Education, Hendek-Sakarya, Turkey \\ ${ }^{2}$ Ministry of Education, Turkey
}

Copyright $(2017$ by authors, all rights reserved. Authors agree that this article remains permanently open access under the terms of the Creative Commons Attribution License 4.0 International License

\begin{abstract}
This research is aimed at examining the validity and reliability of the Turkish version of the Time Attitude Scale. Data were collected from 433 adolescents; 206 males and 227 females participated in the study. Confirmatory factor analysis performed to discover the structural validity of the scale. The internal consistency method was used for reliability analysis. Confirmatory factor analysis revealed a good fit to the data $\left(X^{2}=724.42\right.$, $D F=390, \mathrm{RMSEA}=.045, \mathrm{GFI}=.90, \mathrm{CFI}=.91, \mathrm{IFI}=.91$, NNFI $=.90$, and SRMR $=.04)$. The internal consistency coefficients of six subscales were found to be .67 for past positive, .72 for past negative, .81 for present positive, .72 for present negative, .77 for future positive, and .63 for future negative. The result of the item analysis showed that corrected item-total correlations ranged from .29 to .67 , and were statistically significant at the $p<0.001$ level. These results evidenced that the Turkish version of the scale is a valid and reliable instrument.
\end{abstract}

Keywords Adolescent, Time Attitude, Validity, Reliability

\section{Introduction}

Time perspective is a multidimensional cognitive-motivational concept (Mello, Bhadare, Feam, Galaviz, Hartmann, \& Worrell [1]; Mello, Worrell, \& Andretta [2]) and cognitive-psychological construct (Worrell, Mello \& Buhl [20]) that refers to thoughts and attitudes toward the past, the present, and the future (Mello et al., 2009a [1]). Time perspective comprises many dimensions and encapsulates attitudes toward time (Worrell et al., 2011 [20]). Furthermore, time perspective was described in regards to an orientation, intensity, and attitude toward the past, present, and future (Mello et al., 2009a [1]).

Within the process of cognitive development, while a person is growing up, she or he gains cognitive characteristics that help the person evaluate the passage of time. For instance, during preschool ages, children have not yet developed time consideration (Piaget, 1975 [17]), but when cognitive developments as children grow older, an understanding of time develops. The integration of the self with the past, present, and future is required for identity formation (Ericson [19]), and presumably it is supported by the development of formal operational thinking (McInerney [18]). As a cognitive-motivational construct, time perspective may affect adolescents' present and future behaviors about school and work (Mello et al. [1]). For example, a student may choose to focus on future career decisions and thus presently put more effort into academia in order to have a better career choice in the future.

Lewin (1942) believed that there is an increase in consideration of the future from days to months to even years in the transition from childhood into adolescence (cited in Mello Worrell, \& Andretta [2] p.174). Mello, Bhadare, Feam, Galaviz, Hartmann, \& Worrell [1] also stated that adolescence is a specific developmental period in which it is prudent to examine time perspective. While cognitive capabilities are rising in adolescents, they can better comprehend multiple features and dimensions of time (Worrell \& Mello [3]). These feelings about the past, present, and future are of special consideration for researchers who are particularly interested in adolescence development (Worrell et al. [21]). Age-related variation from childhood into adolescence (and beyond) is an intriguing and important issue when investigating time perspective during adolescence (Mello et al. [2]). In this regard, adolescents' time orientations toward the past, present, and future may be an important tool for understanding their evaluations and feelings about the past, current decisions, and future expectations.

Two scales were developed by researchers (Mello \& Worrell [7]; Zimbardo \& Boyd [5]) in order to assess time perspective and its dimensions. One of those is Zimbardo Time Perspective Inventory (ZTPI) which developed by Zimbardo and Boyd [5]). ZTPI has subscales related to "positive and negative attitudes toward the past, hedonistic and fatalistic attitudes toward the present, and positive, planful attitudes toward the future" (Zimbardo \& Boyd [5]; Milfont \& Gouveia [8]). However, the ZTPI does not have a subscale related to negative attitudes toward the 
future, which was addressed as a shortcoming for the Swedish sample (Carelli, Wiberg, \& Wiberg, [6]). This shortcoming was eliminated in Mello and Worrell's [4] Adolescent Time Inventory (ATI). The ATI has six subscales and measures adolescents' thinking and feeling about the past, present, and future with both positive and negative aspects of all of the measurements.

ATI consists of several components, and each component may be used separately or in combination with one another (Mello \& Worrell [7]; Mello et al. [1]):

- Time meaning: a person's definitions of the past, present, and future.

- Time frequency: the frequency of a person's thoughts being related to the past, present, and future.

- Time orientation: the emphasis that a person places on each time period.

- Time relation: the degree that a person comprehends the past, present, and future to be related.

- Time attitudes: positive and negative attitudes related to the past, present, and future.

Finally, Worrell et al. [20] developed the Adolescent Time Attitude Scale's (ATAS) in both English and German language versions. The ATAS comprises six subscales: "Past Positive, Past Negative, Present Positive, Present Negative, Future Positive, and Future Negative time attitudes." Yet a total score from all subscales is not available.

There are other adaptation studies in various countries related to the ATAS. Fit indices are given in Table 1 (Mello \& Worrell [21]).
In Turkey, there is no instrument that assesses adolescents' time attitude. The items and related factors are stated in Figure 1. Therefore, the purpose of this research is to adapt the ATAS (Worrell et al. [20]) into Turkish and to examine the validity and reliability of the Turkish version.

\section{Materials and Methods}

\subsection{Participants}

The study group consisted of 433 eighth-grade students from schools of Sultangazi, Istanbul. Of these students, 206 were male and 227 were female. Voluntary participation was asked and anonymous data collection was guaranteed to the participants during the application of the scale in the face to face classroom setting.

\subsection{Instrument}

\subsubsection{Adolescent Time Attitude Scale}

The scale (ATAS) was developed by Worrell et al. [20] in order to assess time attitude of adolescents. The measure consists of 30 items and includes 6 factors named as "past positive, past negative, present positive, present negative, future positive, future negative." Each factor of scale has five items. It is a self-report measure of adolescents' time attitudes. Items are rated from 1 (strongly disagree) to 5 (strongly agree). In Table 2, factors and related items are presented.

Table 1. Fit Indices by Country

\begin{tabular}{|c|c|c|c|c|c|c|}
\hline Fit Indices by Country & $X^{2} / d f$ & NNFI $>.90$ & CFI $>.90$ & SRMR $<.08$ & RMSEA $<.05$ & $95 \%$ C.I. \\
\hline US 1 & 1.40 & .937 & .944 & .059 & .037 & $.029, .044$ \\
\hline US2 & 1.75 & .959 & .963 & .045 & .032 & $.028, .036$ \\
\hline US3 & 2.83 & .946 & .952 & .038 & .041 & $.038, .044$ \\
\hline Germany & 1.34 & .960 & .965 & .050 & .033 & $.025, .040$ \\
\hline New Zealand & 1.97 & .950 & .955 & .045 & .041 & $.037, .045$ \\
\hline Iran & 3.23 & .926 & .935 & .061 & .043 & $.40, .046$ \\
\hline China & 1.46 & .902 & .912 & .065 & .042 & $.034, .049$ \\
\hline Northern Ireland & 2.86 & .938 & .944 & .038 & .034 & $.032, .037$ \\
\hline Scotland & 2.07 & .927 & .935 & .044 & .036 & $.033, .040$ \\
\hline Nigeria ("28 items") & 1.32 & .895 & .907 & .074 & .040 & $.029, .050$ \\
\hline Albania ("28 items") & 1.49 & .944 & .951 & .050 & .045 & $.036, .053$ \\
\hline Italy ("28 items") & 1.42 & .911 & .921 & .054 & .037 & $.029, .044$ \\
\hline
\end{tabular}

Reprinted with permission from Mello \& Worrell, 2016, p.3

Table 2. Adolescent Time Attitude Scale Factors and Related Items

\begin{tabular}{cccccc}
\hline PSTN & PSTP & PRN & PRP & FN & FP \\
\hline 6 & 3 & 2 & 5 & 4 & 1 \\
12 & 9 & 8 & 11 & 10 & 7 \\
15 & 21 & 20 & 14 & 16 & 13 \\
18 & 24 & 23 & 17 & 22 & 19 \\
27 & 30 & 29 & 26 & 25 & 28 \\
\hline
\end{tabular}

PSTN: Past Negative; PSTP: Past Positive

PRN: Present Negative; PRP: Present Positive

FN: Future Negative; FP: Future Positive 


\subsection{Data Analysis}

The authors of the paper describing the psychometric properties of the Time Attitude Scale were asked for permission to adapt the ATAS into Turkish. The translation process was done by three expert translators, firstly into Turkish and then a back-translation into English again to check for consistency. As in a scale adaptation process, confirmatory factor analysis (CFA) was performed for structural validity. The internal consistency coefficient $(\alpha)$ was used to determine the reliability level of the scale. For item analysis, corrected item-total correlation was performed.

\section{Findings}

\subsection{Structural Validity}

The CFA was used for the structural validity of the scale, whether the adapted Turkish version and the original scale held the same factors of the ATAS that were reported by Worrell et al. [20].

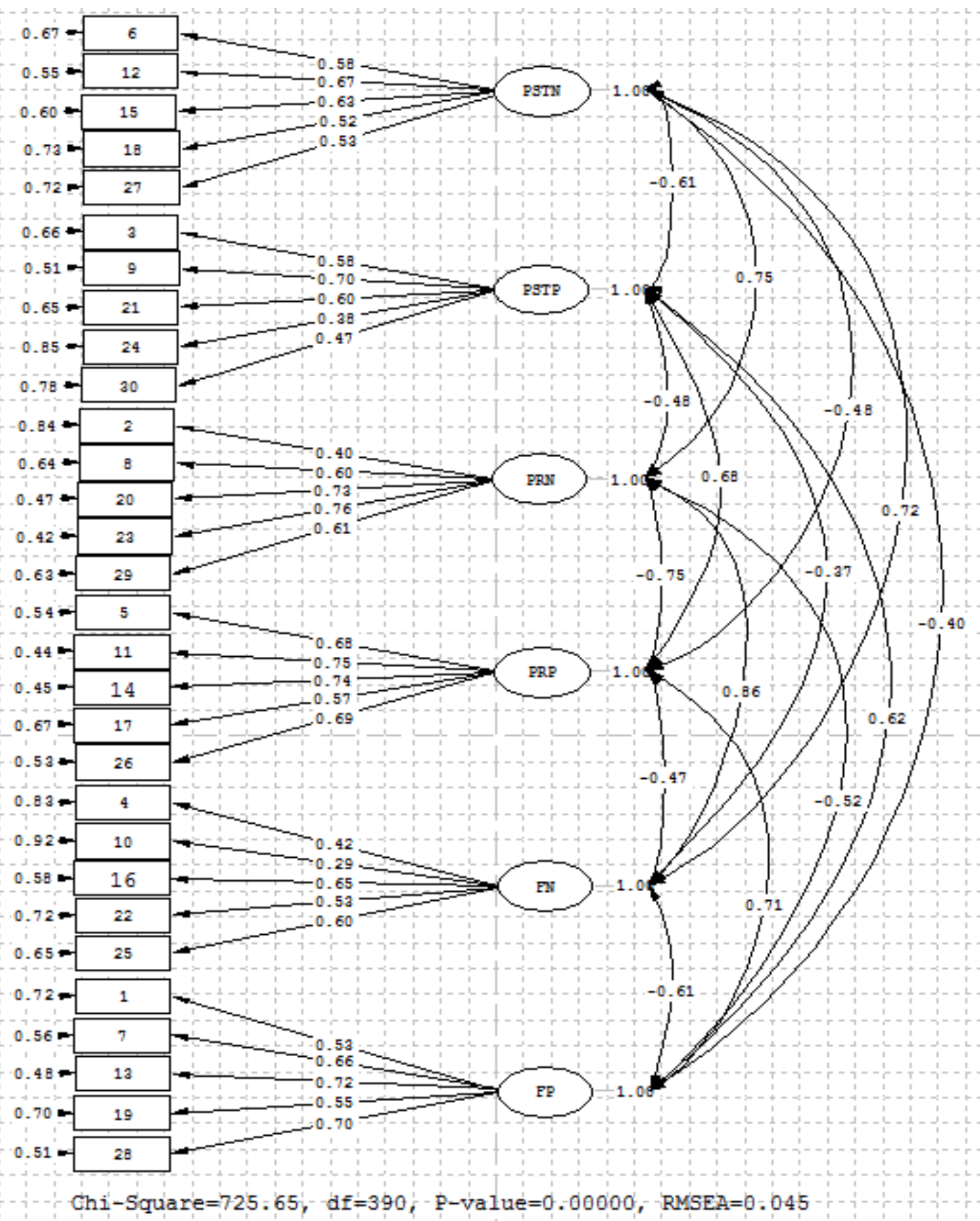

Figure 1. Path diagram and factor loadings related to the Time Attitude Scale (PSTN= Past Negative, PSTP $=$ Past Positive, PRN= Present Negative, PRP= Present Positive, FN= Future Negative, FP= Future Positive) 


\subsection{Confirmatory Factor Analysis}

According to the result of CFA analysis, the model's chi-square values were acceptable $\left(X^{2}=724.42, D F=390\right.$, $p=0.0000$ ). Furthermore, accordance index values were $\mathrm{RMSEA}=.045, \mathrm{GFI}=.90, \mathrm{CFI}=.91, \mathrm{IFI}=.91, \mathrm{AGFI}=.88$, and $\mathrm{SRMR}=.04$. All structural paths were statistically significant at the 0.05 level and are represented in Figure 1. The fit indices of model were evaluated considering the criteria stated by Scheele-Engel, Moosbrugger, and Müller [9]. According to Schermelleh-Engel et al. [9], the reasonable fit indices were shown in Table 3.

Table 3. The Reasonable Fit Indices

\begin{tabular}{cc}
\hline Index & Acceptable Value \\
\hline DF & $0 \leq X^{2} / D F \leq 3(X 2 / D F)$ \\
$p$ & $0.01 \leq p \leq 1.00$ \\
RMSEA & $0 \leq \mathrm{RMSEA} \leq .08$ \\
AGFI & $0.85 \leq \mathrm{AGFI} \leq 1.00$ \\
NFI & $0.90 \leq \mathrm{NFI} \leq 1.00$ \\
NNFI & $0.95 \leq \mathrm{NNFI} \leq 1.00$ \\
CFI & $0.95 \leq \mathrm{CFI} \leq 1.00$ \\
GFI & $90 \leq \mathrm{GFI} \leq 1.00$ \\
SRMR & $0 \leq \mathrm{SRMR} \leq 0.10$ \\
\hline
\end{tabular}

However, some of the results should be discussed depending on explanations of Schermelleh-Engel et al. [9]. The values were $X^{2} / D F(725.65 / 390=1.86 \leq 3)$, the RMSEA $(.045 \leq 0.08)$, the AGFI $(0.85 \leq .88 \leq 1.00)$, the GFI $(.90 \leq .90 \leq 1.00)$, the IFI $(0.90 \leq .91 \leq 1.00$, and the SRMR $(0 \leq .04 \leq 0.10)$ as required. Besides these appropriate results as advised by Schermelleh-Engel et al. [9], the results of the comparative fit index (CFI) were outside of the suggested values. This model was evaluated according to the chi-squared because the $p$ value is affected by the size of the sample. Furthermore, the CFI value was .91 which was not in the recommended range $(0.95 \leq \mathrm{CFI} \leq 1.00)$ according to Schermelleh-Engel at al. [9]. However, according to $\mathrm{Hu}$ and Bentler [10], a CFI value of .90 or larger is usually accepted as a sufficient model fit.

Although there are several opinions, Kline [11] suggested that the chi-squared test, the RMSEA, the CFI, and the SRMR values are the common consideration for model fit. Taking all these explanations and recommendations into account, the results revealed that this model has acceptable fit indices.

\subsection{Reliability}

Cronbach's (1951) alpha coefficient ( $\alpha$ ) was calculated for each of the six subscales. Their internal consistency coefficients $(\alpha)$ were found to be .77 for positive future; .63 for negative future; .81 for positive present; .72 for negative present; .67 for positive past; and .72 for negative past. In summary, values ranged from .63 to .77 , and were statistically significant at the $p<0.001$ level. Flynn, Schroeder, \& Sakakibara [12] stated that an internal consistency coefficient of .60 and above was accepted as a sufficient reliability level for a scale.

\subsection{Item Analysis}

Corrected item-test correlations were used for item analysis. The findings of the item analysis are shown in Table 4.

Table 4. Corrected Item-total Correlations

\begin{tabular}{cl}
\hline Items & $\mathbf{r}_{\mathbf{j x}}$ \\
\hline $\mathbf{1 .}$ & .47 \\
$\mathbf{2 .}$ & .36 \\
$\mathbf{3 .}$ & .46 \\
$\mathbf{4 .}$ & .34 \\
$\mathbf{5 .}$ & .58 \\
$\mathbf{6 .}$ & .46 \\
$\mathbf{7 .}$ & .57 \\
$\mathbf{8 .}$ & .51 \\
$\mathbf{9 .}$ & .50 \\
$\mathbf{1 0 .}$ & .29 \\
$\mathbf{1 1 .}$ & .66 \\
$\mathbf{1 2 .}$ & .55 \\
$\mathbf{1 3 .}$ & .58 \\
$\mathbf{1 4 .}$ & .67 \\
$\mathbf{1 5 .}$ & .52 \\
$\mathbf{1 6 .}$ & .41 \\
$\mathbf{1 7 .}$ & .51 \\
$\mathbf{1 8 .}$ & .43 \\
$\mathbf{1 9 .}$ & .48 \\
$\mathbf{2 0 .}$ & .58 \\
$\mathbf{2 1 .}$ & .43 \\
$\mathbf{2 2 .}$ & .44 \\
$\mathbf{2 3 .}$ & .59 \\
$\mathbf{2 4}$. & .35 \\
$\mathbf{2 5 .}$ & .43 \\
$\mathbf{2 6 .}$ & .61 \\
$\mathbf{2 7 .}$ & .44 \\
$\mathbf{2 8 .}$ & .62 \\
$\mathbf{2 9}$. & .49 \\
$\mathbf{3 0 .}$ & .40 \\
\hline
\end{tabular}

Item analyses were statistically significant at the level of $p<0.001$, and corrected item-total correlations were ranged from .29 to .67 in the present study.

\section{Discussion and Results}

The purpose of the present study was to adapt the adolescent time attitude scale into Turkish and to examine the psychometric properties of the scale. According to the results of the CFA, the model provided a good fit to the data and the original and adapted factor structures were similar. In order to determine the reliability of the scale, an internal consistency coefficient $(\alpha)$ calculation was implemented. For the item analysis, the corrected item-total correlation was applied. The results of these analyses revealed significant evidence that the scale is a reliable instrument. Tezbaşaran [13] suggested that the minimum reliability level for a measurement tool is .70. Furthermore, Flynn et al. [12] stated that an internal consistency coefficient $(\alpha)$ of .60 and above was accepted as a sufficient reliability level for a scale. 
In item analysis, corrected item total correlations values are usually suggested above .30 (Büyüköztürk, [14]). However, Özdamar [23] stated that corrected item total correlation values should be higher than .25 , even though it is not a definite rule. In this study, one of the item's value (item 10) is below 30 (.29), but it is appropriate for the explanations of Özdamar [23]. In this regard, it can be suggested that the present scale has a high enough reliability level. In terms of validity, Büyüköztürk [14] suggested that .30 and higher loadings of items have enough values to differentiate items on any assessed variable. As a result, the ATAS has satisfactory item total correlations. All of the findings related to the reliability and validity analysis support the Turkish form of the ATAS as being a reliable and valid instrument.

A CFA was applied to confirm the six-factor structure of the Turkish form of the ATAS, and the structure of the Turkish form of the ATAS was confirmed to be in the original ATAS form. According to the result of the analysis, the model's accordance indexes and chi-square value were acceptable. All structural paths were statistically significant at the 0.05 level as presented in Section 3.2.

The results also revealed that there were some relations between subscales of the ATAS. For instance, there were positive relationships between positive time attitude perceptions, regardless of the time perspective (past, present, or future). The same result, positive relationships, were also found between negative time attitude perceptions. Conversely, between positive and negative time perspectives, there were negative relations regardless of the time perspective, as predicted. In other words, if the time attitude of the adolescents related to the past is negative, the present and the future time attitude is also negative because of the positive correlation among them. The same case was valid for the positive time attitudes.

It can be said that if memories of the past were negatively evaluated by the adolescent, then it follows that the evaluations of the present and expectations about the future would also be evaluated negatively. Further, if the present is perceived negatively, the future expectations would be negative, or vice versa for positive evaluations. These findings are also supported by the process of therapeutic relationships and psychopathological symptoms, which are generally rooted in past or present traumatic life events (D'Andrea, Sharma, Zelechoski, \& Spinazzola [15]; Anda et al. [16]). This correlation is indicative of the aim of psychotherapies to encourage patients to accept or positively reconstruct (cognitively or emotionally) traumatic events from the past and the present. According to Roediger [22], past life experiences, including personal traumas can unconsciously penetrate into present life events and related experiences. As a result, the present is shaped by past events and experiences. During the psychotherapy process, even though the past cannot be changed, the cognitive and emotional content of the individual's experiences can be reconstructed, so that the present and the future attitudes of the individual can be more positive.

This study has some limitations. At first glance, the data was collected only from students aged 13-15 years. In terms of generalization, this means that the Turkish adaptation scale is better to use for adolescents of this age group. In this study, data about the social and economic statuses and different parental attitude styles were not gathered from the participants. Thus, further research should study a group of adolescents who come from different social and economic backgrounds, have grown up under different conditions, have various family attitudes, and have an extended range of ages. In Turkish, a parallel or opposite scale could not be found, so further studies that will use the adolescent time attitude scale and examine the concurrent validity and test-retest reliability are important for the scale's psychometric strength.

\section{Appendix}

Turkish Form of the Time Attitude Scale

\begin{tabular}{|c|c|}
\hline 1 & Geleceğimi dört gözle bekliyorum. \\
\hline 2 & Şuan yaşamımdan memnun değilim. \\
\hline 3 & Çocukluğumda yaşamış olduğum çok mutlu anılarım var. \\
\hline 4 & Kendi kendime bir şey yapabileceğim konusunda şüpheliyim. \\
\hline 5 & Şu an ki yaşamımda mutluyum. \\
\hline 6 & Geçmiş yaşantımı unutmak isterdim. \\
\hline 7 & Geleceğim beni mutlu ediyor. \\
\hline 8 & Şu anki durumumla ilgili olumsuz duygularım var. \\
\hline 9 & Büyürken güzel anılarım oldu. \\
\hline 10 & Büyüyünce daha önemli bir insan olacağımı düşünmüyorum. \\
\hline 11 & Bugünkü durumumdan memnunum. \\
\hline 12 & Geçmiş halimden memnun değilim. \\
\hline 13 & Geleceğim beni gülümsetiyor. \\
\hline 14 & Mevcut halimden memnunum. \\
\hline 15 & Geçmişim beni üzüyor. \\
\hline 16 & Geleceğim hakkındaki düşünceler beni üzüyor. \\
\hline 17 & Genel olarak, şimdiki yaptığım şeyden memnunum. \\
\hline 18 & Bu geçmişe sahip olmamayı dilerdim. \\
\hline 19 & Geleceğimle ilgili heyecan duyuyorum. \\
\hline 20 & Şimdiki halimden memnun değilim. \\
\hline 21 & Geçmişimle ilgili mutluluk verici düşüncelere sahibim. \\
\hline 22 & Geleceğim hakkında düşünmekten hoşlanmıyorum. \\
\hline 23 & Şimdiki yaşamımda mutlu değilim. \\
\hline 24 & $\begin{array}{l}\text { Geçmiş yaşamımla ilgili düşünmekten hoşlanırım çünkü o } \\
\text { zamanlar mutluydum }\end{array}$ \\
\hline 25 & İleriyi düşünmek anlamsızdır. \\
\hline 26 & Genel olarak, şimdiki yaşamımda mutluyum. \\
\hline 27 & Geçmişim hakkında hoş olmayan düşüncelerim var. \\
\hline 28 & Geleceğim hakkında düşünmek beni heyecanlandırır. \\
\hline 29 & Şimdiki yaşamım beni endişelendirir. \\
\hline 30 & Geçmişim tamamen mutlu anılarla doludur. \\
\hline
\end{tabular}

\section{REFERENCES}

[1] Mello, Z. R., Bhadare, D., Feam, E. J., Galaviz, M. M., Hartmann, E. S., \& Worrell, F. C. (2009a). The window, the river, and the novel: examining adolescents' conceptions of the past, the present, and the future. Adolescence, 44, 175, 539-556. 
[2] Mello, Z. R., Worrell, F. C., \& Andretta, J. R. (2009b). Variation in how frequently adolescents think about the past, the present, and the future in relation to academic achievement. Diskurs Kindheits- und Jugendforschung Heft, 2, 173-183.

[3] Worrell, F. C., \& Mello, Z. R. (2007). The reliability and validity of Zimbardo Time Perspective Inventory scores in academically talented adolescents. Educational and Psychological Measurement, 67(3), 487-504.

[4] Mello, Z. R., \& Worrell, F. C. (2007). The adolescent time perspective inventory-English. University of California, Berkeley.

[5] Zimbardo, P. G., \& Boyd, J. N. (1999). Putting time in perspective: A valid, reliable individual difference metric. Journal of Personality and Social Psychology, 77(6), 1271-1288.

[6] Carelli, M. G., Wiberg, B., \& Wiberg, M. (2011). Development and construct validation of the Swedish Zimbardo time perspective inventory. European Journal of Psychological Assessment, 27(4), 220-227. doi: http://dx.doi.org/10.1027/1015-5759/a000076

[7] Mello, Z. R., \& Worrell, F. C. (2012). The adolescent time inventory. preliminary technical manual. Version 2.0. Colorado Spring, Colorado \& Berkeley, California.

[8] Milfont, T. L., \& Gouveia, V. V. (2006). Time perspective and values: An exploratory study of their relations to environmental attitudes. Journal of Environmental Psychology, 26(1), 72-82.

[9] Schermelleh-Engel, K., Moosbrugger, H., \& Müller, H. (2003).Evaluating the fit of structural equation models: Tests of significance and descriptive goodness-of-fit measures. Methods of Psychological Research Online, 8, 23-74.

[10] Hu, L., \& Bentler, P. M. (1999). Cutoff criteria for fit indexes in covariance structure analysis: Conventional criteria versus new alternatives. Structural Equation Modeling, 6, 1-55.

[11] Kline, R. B. (2010). Principles and practice of structural equation modeling ( $3 r d$ ed.). New York, New York: Guilford Press.

[12] Flynn, B., Schroeder, R., \& Sakakibara, S. (1994). A framework for quality management research and an associated measurement instrument. Journal of Operations Management, 11, 339-366.

http://dx.doi.org/10.1016/S0272-6963(97)90004-8

[13] Tezbaşaran, A. (1996). Likert tipi ölçek geliştirme klavuzu. Ankara: Psikologlar Derneği Yayınları.

[14] Büyüköztürk, Ş. (2010). Sosyal bilimler için veri analizi el kitabı. Ankara: PegemA Akademi Yayınevi.

[15] D’Andrea, W., Sharma, R., Zelechoski, A. D., \& Spinazzola, J. (2011). Physical Health Problems After Single Trauma Exposure When Stress Takes Root in the Body. Journal of the American Psychiatric Nurses Association, 17(6), 378-392.

[16] Anda, R. F., Felitti, V. J., Bremner, J. D., Walker, J. D., Whitfield, C. H., Perry, B. D., Dube, R. S., \& Giles, W. H. (2006). The enduring effects of abuse and related adverse experiences in childhood. European archives of psychiatry and clinical neuroscience, 256(3), 174-186. DOI 10.1007/s00406-005-0624-4.

[17] Piaget, J. (1975). The intellectual development of the adolescent. In A. H. Esman (Ed.), The Psychology of the Adolescence: Essential Readings (pp. 104-108). New York: International Universities Press.

[18] McInerney, D. M. (2004). A discussion of future time perspective. Educational Psychology Review, 16, 141-151.

[19] Erikson, E. H. (1968). Identity: Youth and crisis. New York: Norton.

[20] Worrell, F. C., Mello, Z. R., \& Buhl, M. (2011). Introducing English and German Versions of the Adolescent Time Attitude Scale. Assessment, 20(4), 496-510.

[21] Mello, Z. R., \& Worrell, F. C. (2016). The Adolescent Time Inventory Technical Manual. San Francisco, California \& Berkeley, California

[22] Roediger, E. (2012).Şema Terapi Nedir? Şema terapinin Temellerine, Modellerine ve Uygulamalarına Giriş (Çev. Ed. S. Ataman, Çev. Ed.). Ankara: Nobel Akademik Yayıncılık.

[23] Özdamar, K. (1997). Paket Programlar ile İstatistiksel Veri Analizi-1. Anadolu Üniverstesi Fen Fakültesi Yayınları, No:11. Eskişehir. 